\title{
Investigation on Entrepreneurship Trends of Tourism Faculty Students
}

\author{
Ersan Erol \\ Eşkişehir Osmangazi University Tourism Faculty, ESOGÜ Meşelik Campus, \\ Eskişehir, Turkey, ersane@ogu.edu.tr
}

\section{Mustafa Aksoy}

Gazi University Tourism Faculty, Gölbaşı Campus, Ankara, Turkey, maksoy@gazi.edu.tr

\begin{abstract}
It has become inevitable to come across with a new service approach, a new idea of business or a new discovery nowadays, so there is a global economy and its supporting platforms for the entrepreneurs to realize their business ideas and plans. In the study, it was aimed to identify the university students entrepreneurial tendency. Thus, " entrepreneurship" was tried to explained through literature review. In application part, the tourism faculty students at Gazi University and Eskişehir Osmangazi University were asked complete questionnaires online. In the questionnaire, it was verified that all of the items that are the results of the factor analysis carried out with "Basic Component Analysis" were collected in one dimension. The Cronbach's alpha reliability coefficient of the reliability scale was found to be 0.90 as the result of the reliability analysis. In the research, arithmetic average, standard deviation, independent t-test and Anova tests were used.
\end{abstract}

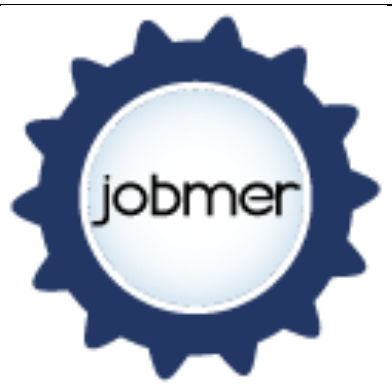

Journal of Business Management and Economic Research Vol.2, Issue.1, 2018 pp. 31-44

Doi: $10.29226 /$ TR1001.2018.8

Keywords: Entrepreneurship, Tourism Faculty 


\section{Introduction}

Entrepreneurship, as the driving force of economic, political and cultural life, increases the level of prosperity in the individual and social sense. The absence of the entrepreneurship culture in Turkey is due to the lack of production powers rather than shortages in the resources. It is not the richness of the natural resources, but the richness of the human resources that is determinant in overcoming the absence of production powers (Gürdoğan, 2008, p. 12).

While the economic value of the physical power of the human has rapidly been decreasing in the information societies, the economic value of intellectual labor has begun to increase at a faster pace (Balaban and Özdemir, 2008, p. 134). Accordingly, concepts such as innovation, taking risks, tolerance to the uncertain conditions, need for success and control center are frequently emphasized. The concept of entrepreneurship has been regarded as a fundamental factor in development and progress in every area (Bozkurt, 2006, p. 94).

Universities raise leaders, who are entrepreneurs and know how to innovate and take risks, and form networks with hundreds of managers rather than forming giant organizations governed by a single person; whether it is an organization in the public or private sector or a voluntary institution (Gürdoğan, 2008, p. 12). Entrepreneurship classes had mainly focused on engineering, business, economics, and etc.; however, today, it is known that entrepreneurship is a subject or lesson that should be given in all levels and branches of education regardless of the branch (Deveci and Çepni, 2015, p. 93).

Entrepreneurship, which has become increasingly important with increasing competition in free market conditions, has been encouraged by the possibilities, trainings and supports provided by the government along with the projects. Today, however, the programs that universities have under the name of entrepreneurship cause the entrepreneurship to emerge as a professional phenomenon and to be evaluated in an institutional structure. With this purpose, the universities organize a variety of activities and trainings, having an important place in the development of entrepreneurship characteristics of individuals.

Today, however, the entrepreneurship rates of the university graduates stay in a low level. While there are numerous causes for that, their self-perception of being insufficient in financial sense and their deficiencies in experience and personal characteristics are the main reasons. (Galloway and Brown, 2002, p. 400).

In order to prevent these reasons; universities must carry out activities related to the sustainability of the entrepreneurship culture and creativity, courses about business development and finance and etc., as well as the special training programs to develop individual skills (Klofsten, 2000, p. 338). To have successful entrepreneurs in a society and to increase the numbers of entrepreneurs, potential entrepreneurs, who have had entrepreneurship training and have the desire to become entrepreneurs should be directed to this field (İscan ve Kaygın, 2011, p. 276). The purposes at this point are 
students' starting their own initiatives and developing the skills of existing entrepreneurs (Rasmussen and Sorheim, 2006, p. 186).

Especially, in Turkey, it is very important to develop the students', who take the step to the university, entrepreneurial aspects and to equip them with the knowledge and skills that they will be able to realize their environments and potentials, change the problems into opportunities, and providing them to be able to take risks by raising them as encouraged people without suppressing their creativity (Titiz, 1999, p. 3).

The purposes of this study were to determine the factors affecting the entrepreneurship tendencies and interests of the university students, and to investigate the effect of demographic characteristics on these factors and to reveal the current dynamic structure. Within the scope of the research, a survey was performed with the students of Gazi University and Osmangazi University Tourism Faculties.

\section{Entrepreneurship}

Entrepreneurship has been one of the topics studied by many theoreticians due to its positive contributions to economic and social life, in every period of human history. The word entrepreneurship is derived from the word entrepreneur, which is based on the French word "enterprise" (Kantur, 2007, p. 133).

The widely known definition of entrepreneurship was first made by Richard Cantillon (Döm, 2008, p. 1). Cantillon explains entrepreneurship by evaluating entrepreneurship on a scientific ground with the ability to take risks; as being the person, who organizes the activities and undertakes the risks due to the uncertainty environment with the purpose of making profit (Hébert and Link, 1988, p. 33).

Since the French economist JB Say, entrepreneurship has been regarded as the fourth factor of production. Thus, the entrepreneurship is included in the classical factors of production, which are labor, capital and nature (Müftüoğlu and Durukan, 2004, 6). In the $18^{\text {th }}$ century, Jean Batiste Say states that entrepreneurship emerged as the result of "accepting good or bad chances of production in advance" (Say, 1972, transcribed by Alada, 2001, p. 49). Marshall's concept of entrepreneur defines entrepreneurship as the realization of management activities and the production of goods and services together with the innovations, in the basic sense (Praag, 1999, p. 319; Glancey, 2007, p. 6). In other words, the entrepreneur manages the production processes, coordinates the labor and capital resources by taking the risk of uncertainty (Kılıç and Aydın, 2015, p. 148).

Another person contributing to entrepreneurship literature is Max Weber. Weber defines entrepreneurship in a capitalist structure as "an action based on profit opportunities" and a "person seeking for profit" (Weber, 2015, p. 17-18). Joseph Scumpeter describes the entrepreneur by constructing the definition on the concept of "innovative", as a person who takes risk, innovates and leads this process with the aim of making profit (Arıkan, 2004, p. 7-8, Kizılkaya, 2005, p. 39, Döm 2008, p. 4). Frank Knight, who has made a significant contribution to the theory of entrepreneurship, describes a successful entrepreneur by being successful undertaking the uncertainties and in judicial decision-making, by revealing the difference between risk and uncertainty (Praag, 2007, p. 322). 
Since there are different definitions of entrepreneurship, while Schumpeter, Baudeau, Bentham, Schmoller, Sombart, Thünen, and Weber have suggested the entrepreneur as innovative, Say did not approach in the same way (Ripsas, 1998, p. 106; Turan, et al, 2015, p. 922). While Mil, Knight, Hawley, Shakle, Thünen, Mises, Cole and Cantillon emphasized "taking risks" in their discourses, Say, Saint-Simon, Amasa Walker, Francis Walker, Weber, Clark, Davenport, Schumpeter, and Coase stressed "Leadership", Knight and Cantillon stated "creating opportunities from uncertainties", Kirzner, Kirchoff and Leibenstain expressed "creating opportunities in the market", Cole, Cantillon and Say addressed "organizing the business", Smith stated "capitalist", Menger, Kynnes and Mises, Marshall and Say highlighted "manager", Say, Walras, Wieser, Schmoller, Sombart, Weber, Clark, Davenport, Schumpeter, and Coase stressed "organization and coordination", Cantillon Menger, Marschall, Wieser, Amasa Walker, Francis Walker, Keynes, Kynnes, Mises, Shaklee, Cole, and Schultz emphasized “decision-maker" (Hébert and Link 1988, p. 152, Ripsas, 1998, p. 106)

The concept of entrepreneurship, which has been changing and evolving with time, is defined as taking more risks, catching up with innovations, making use of opportunities and realizing all of them (Keleş, et al, 2012, p. 108), creating values that have economical, sociological and psychological revenues and require special effort (Wennekers and Thurik, 1999, p. 7) and a process of deciding on the use of resources by perceiving economic opportunities, revealing new opportunities, presenting ideas to the market, and considering ambiguity and other obstacles together with those, by an individual or via a teamwork Wennekers and Thurik, 1999, p. 46)

In the broadest terms, entrepreneur is the innovative person who determines opportunities and developments in the market, transforms market opportunities and changes into business ideas, takes risks and combines the labor, capital and natural resources, which are production factors, and is able manage an enterprise successfully (Tekin, 2004, p. 4).

As it may be seen, it is not possible to make a single definition of entrepreneurship. The reason for this is that the entrepreneurship is a dynamic structure and it is constantly changing (Bilge ve Bal, 2012, p. 133). However, the common point of the definitions about the entrepreneur is that the entrepreneur is able to see the opportunities that others cannot see and turn them into business ideas, and he/she is prone to take risks (Akat et al, p. 1997, p. 13).

Therefore, not taking risks is not a matter of question in entrepreneurship. However, the biggest mistake that is made in this process is to act individually in environments where innovative thinking does not exist. Entrepreneurship not only involves exposing the new one but also making appropriate investments with little risk by acting together.

The factors that are effective in entrepreneurship have changed in parallel with the characteristics of the current period. With this change, the answers given to the question of who the entrepreneur is and what characteristics he/she should carry have also been differentiated (Arikan, 2002). For example, the personal characteristics of entrepreneurs are expressed as being open to innovation, prone to risk-taking, creative, 
talented and opportunity oriented (Cansiz, 2007, p. 28), recognizing the opportunities, motivated for success (Hartman, 1959), having optimism, success, power, honesty (McClelland, 1961), motivated for success, internal control (Durand, 1975), having success, autonomy, aggressiveness, independence, leadership (DeCarlo and Lyons, 1979), being prone to taking risks (Brochous, 1980), having ambition and discipline, motivation for success, (Hisrich and O Brien, 1981), as the results of various researches (McClelland, 1961; Durand, 1975; DeCarlo and Lyons, 1979; Brochous, 1980; Hisrich and O Brien, 1981; Gartner, 1988, 51-55).

Despite the fact that the characteristics of an entrepreneur are mentioned in many studies, it is difficult to see and construct a list of features, which is generally accepted in the literature. However, from the personal point of view; ambition for a high success, autonomy and influence, tolerance for uncertainty, high risk-taking tendency, compliance and flexibility, self-respect, self-confidence and opportunism (McClelland, 1961; Brush, 1992; Schein et al., 1996; Schwartz 1997; Hirsch and Brush, 1987; Buttner and Moore, 1997; Cuba et al., 1983; Rosa et al., 1994; Kirzner, 1973, 1979, 1997, 1999, transcribed by , Etemad, 2004, p. 18) can be expressed as the common characteristics of entrepreneurship stated by the scientists who had performed researches in this subject.

Entrepreneurship is a fundamental mechanism in the characteristic of the assurance of the creation and dissemination of prosperity that constitutes the focus of the theory of economy (Gürol, 2000, p. 68).Entrepreneurs constantly encounter with doubt and stress (Kuyan, 2007, p. 41). However, there are many benefits of being an entrepreneur or the entrepreneurship at an individual, institutional, regional, national and international scale (Gürer, et. al, 2014, p. 14) Therefore, entrepreneurship, which is the key to the social structure and development of the society, should be improved by providing the necessary infrastructure in every area.

\section{Method}

The purpose of this research is to determine the interests of the university students in entrepreneurship and the level of this interest. The data used in the research were obtained through questionnaires. Sampling method was used to reveal the interests of the Gazi University Tourism Faculty and Osmangazi University Tourism Faculty students in entrepreneurship. In the study, online surveys were conducted on platforms, where the students had been signed up. The final set of samples used in the study consisted of 209 individuals. The questionnaire that was used consisted of two parts. In the first part, there were 9 questions in order to learn the demographic structure of the respondents. In the second part, there were 36 expressions with 5 point likert scale in order to measure the perceptions and attitudes of the participant students regarding entrepreneurship. The answers to the propositions were given from "1. Never" to "5. Very frequently". The propositions used in the questionnaire were taken from the study of Yllmaz nd Sünbül named as "development of an entrepreneurship scale for university students" ( Yılmaz and Sünbül, 2009, p. 202-203).

Miller has used the word "entrepreneur" for the companies that have the tendency of taking risk, innovation and being proactive. These sub-dimensions do not explain a variance that is independent from each other, which means that individuals who do 
not show the tendency of taking risk, innovation and pro-active behaviors spontaneously, cannot be regarded as entrepreneurs (Covin, et al, 2006, transcribed by Wasti and Fis 2009, p. 143). This study has been evaluated on one dimension in this respect.

In the questionnaire, it was verified that all of the items that are the results of the factor analysis carried out with "Basic Component Analysis" were collected in one dimension. The Cronbach's alpha reliability coefficient of the reliability scale was found to be 0.90 as the result of the reliability analysis. In the research, arithmetic average, standard deviation, independent t-test and Anova tests were used. A statistics program pack was used to analyze the data. The following criteria were developed for the evaluation of the entrepreneurship levels of the students (Yılmaz and Sünbül, 2009, p. 198)

The following criteria were taken as the basis in the evaluation of entrepreneurship scores.

\begin{tabular}{|l|l|}
\hline $36-64$ & Very low level of entrepreneurship \\
\hline $65-92$ & Low level of entrepreneurship \\
\hline $93-123$ & Moderate level of entrepreneurship \\
\hline $124-151$ & High level of entrepreneurship \\
\hline $152-180$ & Very high level of entrepreneurship \\
\hline
\end{tabular}

\section{Findings}

Table - 1: Distribution of the Students about the Variables of University, Class, Graduation, Age, Gender and Entrepreneurship Training

\begin{tabular}{llll}
\hline Variables & Categories & $\mathbf{N}$ & $\%$ \\
\hline University & Gazi & 113 & 54.1 \\
& Osmangazi & 96 & 45.9 \\
\hline \multirow{4}{*}{ Class } & $1^{\text {st }}$ Class & 21 & 10 \\
& $2^{\text {nd }}$ Class & 27 & 12.9 \\
& $3^{\text {rd }}$ Class & 71 & 34 \\
& $4^{\text {th }}$ Class & 81 & 38.8 \\
& $5^{\text {th }}$ Class and over & 9 & 4.3 \\
\hline \multirow{3}{*}{ Graduation } & Regular High School & 67 & 32.1 \\
& Anatolian High School & 44 & 21.1 \\
& Vocational High School & 26 & 12.4 \\
& Anatolian Vocational High & 70 & 33.5 \\
& School & 2 & 1 \\
\hline & Open High School & 51 & 24.4 \\
& Aged 18-20 & 138 & 66
\end{tabular}




\begin{tabular}{|c|c|c|c|}
\hline \multirow[t]{3}{*}{ Age } & Aged 24-26 & 15 & 7.2 \\
\hline & Aged 26-30 & 4 & 1.9 \\
\hline & 31 and Over & 1 & 0.5 \\
\hline \multirow[b]{2}{*}{ Gender } & Female & 83 & 39.7 \\
\hline & Male & 126 & 60.3 \\
\hline \multirow[b]{2}{*}{ Entrepreneurship Training } & Yes & 89 & 42.6 \\
\hline & No & 120 & 57.4 \\
\hline \multirow{5}{*}{$\begin{array}{l}\text { Number of People in Family } \\
\text { Working as Paid Employees }\end{array}$} & None & 26 & 12.4 \\
\hline & 1 & 96 & 45.9 \\
\hline & 2 & 66 & 31.6 \\
\hline & 3 & 19 & 9.1 \\
\hline & 4 & 2 & 1 \\
\hline \multirow[t]{2}{*}{ Variables } & Categories & $\mathbf{N}$ & $\%$ \\
\hline & 1 & 67 & 32.1 \\
\hline \multirow{2}{*}{$\begin{array}{l}\text { Number of People in Family } \\
\text { Working for Their Own } \\
\text { Account }\end{array}$} & 2 & 23 & 11 \\
\hline & 3 & 11 & 5.3 \\
\hline \multirow{6}{*}{ Career Goal } & Teacher & 48 & 23 \\
\hline & Academician & 38 & 18.2 \\
\hline & Public Officer & 22 & 10.5 \\
\hline & Private sector & 42 & 20.1 \\
\hline & Own Business & 59 & 28.2 \\
\hline & Total & 209 & 100 \\
\hline
\end{tabular}

When the distribution of the students, who participated in the survey, according to the variable of the university they studied, $54.1 \%$ of them were from Gazi University and $45.9 \%$ of them were from Osmangazi University. In the distribution according to the variable of the class that the students were attending in the Tourism Faculties, where the research was carried out, $10 \%$ of them was at $1^{\text {st }}$ year; $12.9 \%$ of them was at $2^{\text {nd }}$ year; $34 \%$ of them was at $3^{\text {rd }}$ year; $38.8 \%$ of them was at $4^{\text {th }}$ year; and $4.3 \%$ of them was at $5^{\text {th }}$ year and above. According to the data regarding the educational institutions that the participant students had been graduated, it was seen that $32.1 \%$ of the students were graduated from Regular High Schools, $21.1 \%$ of them were graduated from Anatolian High Schools, $12.4 \%$ of them were graduated from Vocational High Schools, 33.5\% of them were graduated from Anatolian Vocational High Schools, and 1\% of them were graduated from Open High Schools.

In the distribution of the variable of ages of the university students, $24.4 \%$ of the students were aged between 18 and 20 years; $66 \%$ of them were aged between 21 and 23 years; $7.2 \%$ of them were aged between 24 and 26 years, $1.9 \%$ of them were aged between 26 and 30 years, and $0.5 \%$ of them were aged 31 years or older. When the distribution of the variable of the gender of the students participating in the survey was examined, $39.7 \%$ of them were identified as females and $60.3 \%$ of them were male. 
When the distribution according to whether the students participating in the research had entrepreneurship training was examined, $42.6 \%$ of them were determined to have previously had entrepreneurship training; and $57.4 \%$ of the respondents had not received entrepreneurship training.

When the distribution of the numbers of the paid employees in the families of the students participating in the survey was examined, $12.4 \%$ of them had no one in the family, $45.9 \%$ had one person, $31.6 \%$ had two persons, $9.1 \%$ had 3 persons, and $1 \%$ had 4 persons in their family. Looking at the distribution of the number of self-employed people in the family of the students participating in the survey, 51.7\% 1 person of $32.1 \%$; $11 \%$ of 2 people; It is seen that $5.3 \%$ of them are 3 persons. In the tourism faculties, where the research was carried out, when the students were asked about their career goals at the end of the university, $23 \%$ of them were planning to be a teacher, $18.2 \%$ of them were planning to be an academician, $10.5 \%$ of them were planning to be a public officer, $20.1 \%$ of them were planning to be in the private sector, and $28.2 \%$ of them were planning to open their own businesses.

Table-2: Difference Analysis between Entrepreneurship Levels and University Variable

\begin{tabular}{lccccc}
\hline University & $\mathbf{N}$ & W. Avg & SD & $\mathbf{t}$ & $\mathbf{p}$ \\
\hline Gazi University & 113 & 146.115 & 17.75 & 0.016 & 0.609 \\
& & & & & \\
Osmangazi University & 96 & 139.990 & 18.59 & 0.016 & 0.609
\end{tabular}

Considering whether there is a differentiation in terms of levels of entrepreneurship regarding the variable of universities of the participating sample group, it was seen that there was no significant difference in the level of 0.05 . While the weighted average of Gazi University students was 146.115 and the weighted average of Osmangazi University students was 139.990; it can be stated that the tendency of entrepreneurship is "High Level of Entrepreneurship", which is between 124-151.

Table - 3: Variance Analysis between Entrepreneurship Levels and the Classes of the Students

\begin{tabular}{lccccc}
\hline Class & N & W. Avg. & SD & F & p \\
\hline $1^{\text {st }}$ Class & 21 & 145.619 & 22.31 & & \\
$2^{\text {nd }}$ Class & 24 & 144.185 & 15.55 & & \\
$3^{\text {rd }}$ Class & 71 & 142.535 & 17.98 & 0.138 & 0,968 \\
$4^{\text {th }}$ Class & 81 & 142.988 & 18.87 & & \\
$5^{\text {th }}$ Class and over & 9 & 144.111 & 17.78 & & \\
\hline
\end{tabular}

When the differentiation of the entrepreneurial tendencies of the sample group participating in the study was evaluated in terms of the variable of their classes, there was no significant difference in 0.05 significance level. The weighted averages of the students were as 145.619 in Class 1; 144.185 in Class 2; 142,535 in Class 3; 142.988 in 
Class 4, and 144.11 in Class 5 and over for their entrepreneurship tendencies, and as these averages were between 124 and 151, it can be called as "High Level of Entrepreneurship".

Table - 4: Variance Analysis between Entrepreneurship Level and Graduation Status

\begin{tabular}{lccccc}
\hline Graduation Status & N & W. Avg. & SD & F & p \\
\hline Regular High School & 67 & 141.761 & 19.52 & & \\
Anatolian High School & 44 & 146.295 & 19.51 & & \\
Vocational High School & 26 & 145.307 & 15.37 & 2.754 & 0.029 \\
Anatolian Vocational High & 70 & 143.242 & 16.55 & & \\
School & & & & & \\
Open High School & 2 & 105.000 & 12.72 & & \\
\hline
\end{tabular}

When the differentiation of the entrepreneurial tendencies of the sample group participating in the study was evaluated in terms of the variable of their graduated high schools, there was a significant difference in 0.05 significance level. The weighted averages of the students were 141.761 for Regular High School; 146.295 for Anatolian High School; 145.307 for Vocational High School; 143.242 for Anatolian Vocational High School, and as these averages were between 124 and 151, it can be called as "High Level of Entrepreneurship". However, with an average of 105.000, it can be seen that Open High School graduates tend to be in "Moderate Level of Entrepreneurship "

Table - 5: Variance Analysis between Entrepreneurship Level and Age

\begin{tabular}{llllll}
\hline Age & $\mathbf{N}$ & W. Avg. & SD & F & p \\
\hline Aged 18-20 & 51 & 143.960 & 18.05 & & \\
Aged 21-23 & 138 & 142.833 & 18.11 & & \\
Aged 24-26 & 15 & 150.200 & 21.16 & & \\
Aged 26-29 & 4 & 124.750 & 11.81 & \multirow{2}{*}{1.61} & 0.173 \\
30 and Over & 1 & 145.000 & 18.36 & & \\
\hline
\end{tabular}

When the differentiation of the entrepreneurial tendencies of the sample group participating in the study was evaluated in terms of the variable of their ages, there was no significant difference in 0.05 significance level. The weighted averages of the students were between 143.960 for ages of 18-20 years; 142.833 for ages of 21-23 years; 150.200 for ages of 24-26 years; 124.750 for ages of 27-29 years, and 145.000 for ages of 30 years and above, and as these averages were between 124 and 151, it can be called as "High Level of Entrepreneurship".

Table - 6: Variance Analysis between Entrepreneurship Level and Gender

\begin{tabular}{lccccc}
\hline Gender & $\mathbf{N}$ & W. Avg. & SD & F & p \\
\hline Female & 83 & 145.506 & 17.54 & 0.159 & 0.159 \\
Male & 126 & 141.000 & 18.80 & 0.154 & \\
\hline
\end{tabular}


When the differentiation of the entrepreneurial tendencies of the sample group participating in the study was evaluated in terms of the variable of their genders, there was no significant difference in 0.05 significance level. The weighted averages of the students were 145.506 for females; and 141.000 for males, and as these averages were between 124 and 151, it can be called as "High Level of Entrepreneurship".

Table 7: Variance Analysis between Entrepreneurship Level and Number of People Working on Their Own Account

\begin{tabular}{lccccc}
\hline $\begin{array}{l}\text { People Working on Their } \\
\text { Own Account in the Family }\end{array}$ & $\mathbf{N}$ & W. Avg. & SD & F & p \\
\hline None & 108 & 139.472 & 18.20 & & \\
1 person & 67 & 148.194 & 17.09 & & \\
2 people & 23 & 144.087 & 19.81 & 3.710 & 0,012 \\
3 People & 11 & 149.454 & 17.60 & & \\
4 people & 0 & & & & \\
\hline
\end{tabular}

When the differentiation of the entrepreneurial tendencies of the sample group participating in the study was evaluated in terms of the variable of the number of people working on their own account, there was a significant difference in 0.05 significance level. The weighted averages of the students were between 124-151 for "None and 1, 2, 3 and 4 people" and it can be said that they are at a "High Level of Entrepreneurship", and there is no student that has 4 people working on their own account.

Table - 8: Variance Analysis between Entrepreneurship Level and Career Goal

\begin{tabular}{lccccc}
\hline Career goal & N & W. Avg. & SD & F & p \\
\hline Teacher & 48 & 140.229 & 20.57 & & \\
Academician & 38 & 143.394 & 18.58 & & \\
Public Officer & 22 & 137.318 & 16.79 & 2.932 & 0.022 \\
Private sector & 48 & 140.229 & 20.57 & & \\
Own Business & 38 & 143.394 & 18.58 & & \\
\hline
\end{tabular}

When the differentiation of the entrepreneurial tendencies of the sample group participating in the study was evaluated in terms of the variable of the career goals, there was a significant difference in 0.05 significance level. The weighted averages of the students were 140.229 for being a teacher; 143.394 for being an academician; 137.318 for being a public officer; 141.000 for being in the Private Sector and 149.610 for being in their own businesses; and as these averages were between 124 and 151, it can be called as "High Level of Entrepreneurship".

\section{Results}

When the distribution of the students according to the variable of the university they studied was examined within the framework of the research; total of 209 questionnaires were applied to the students, of which $45.9 \%$ were from Osmangazi University, $54.1 \%$ were from Gazi University. It was aimed to determine entrepreneurship levels of 
students in the light of the obtained data. The data obtained in the analyzes, which were performed by comparing with the independent variables;

Considering whether there is a differentiation in terms of levels of entrepreneurship regarding the variable of the universities of the participating sample group, it was seen that there was no significant difference in the level of 0.05 . While the weighted average of Gazi University students was 146.115 and the weighted average of Osmangazi University students was 139.990; it can be stated that their tendency is "High Level of Entrepreneurship", which is between 124 and 151. In the study of Balli and Ball (2014), called as "Individual Values and Entrepreneurship Tendencies of University Students", it is also seen that the students show a high level of entrepreneurship tendency.

A differentiation in entrepreneurship tendencies was not determined in terms of the variable of the class level in which the sample group had been studying. When the differentiation of the entrepreneurial tendencies of the sample group participating in the study was evaluated in terms of the variable of their graduated high schools, a significant difference was observed. It was seen that the entrepreneurship tendency of open high school graduates was low. This data enables us to reach the result that the quality of education affects the entrepreneurship training and its level.

When the differentiation of the entrepreneurial tendencies of the sample group participating in the study was evaluated in terms of the variable of their ages, there was no significant difference in 0.05 significance level. Kirılmaz (2013), in the "Research on the Determination of Entrepreneurship and Transformational Leadership Perceptions of Social Entrepreneurs", could not find a significant difference in the perceptions of entrepreneurship, transformational leadership and social entrepreneurship of the social entrepreneurs, according to the ages, in the way that supports our study.

When the differentiation of the entrepreneurial tendencies of the sample group participating in the study was evaluated in terms of the variable of their genders, there was no significant difference in 0.05 significance level. When the entrepreneurship tendency of the students is examined by gender, it is seen that females $(145,506)$ have a higher level of entrepreneurship level than males $(141,000)$.

These results was as, $66.9 \%$ (240) of female students and $72.2 \%$ (156) of the male students showed high and very high entrepreneurship tendency, according to the findings of Köksal and Penez (2015)'s study named "An Analysis on the Demographic Characteristics and Sector Preferences of Young People with High Tendencies of Entrepreneurship in the Universities". Today it is seen that women are in a more productive situation and will have a higher share in the economy with national and international supports.

When the differentiation of the entrepreneurial tendencies of the sample group participating in the study was evaluated in terms of the variable of the number of people working on their own account, there was a significant difference, in 0.05 significance level. Yüzüak (2010) concluded that having an entrepreneur in the family, educated parents and training of entrepreneurship influences the entrepreneurship tendency, in the study named "Factors Affecting the Entrepreneurship Tendencies of Female Students Who Study at Universities"; and this result also supports our study. At the same time, Duygulu (2008) emphasizes that there is a relationship between the situation where 
there are individuals doing their own work in the family and the entrepreneurship attitude of the individual.

In other words, it was observed that the median value of the entrepreneurship level scores was 158.00 for the students who had a family business, and 94.41 for the families without a family business. When the entrepreneurship level scores were evaluated according to Yilmaz and Sünbül's criteria, it was observed that the entrepreneurship levels of the students with family business were "very high" and the entrepreneurship levels of the students without family business were "moderate".

When the differentiation of the entrepreneurial tendencies of the sample group participating in the study was evaluated in terms of the variable of career goals, it is seen that, there was a significant difference. It is observed that the tendency of entrepreneurship of students who want to work in the public sector is lower than those who want to work in the private sector.

The extension of the working sample group and its application to different departments with more universities can be suggested for those who want to do research on the subject.

In addition, it is evaluated that, the fact that the level of entrepreneurship in women is higher than men is quite remarkable. With the help of data obtained from this study, it will be useful to study entrepreneurship levels among university graduates and to determine the characteristics of existing entrepreneurs, as well as performing studies aimed at contributing in the enhancement of entrepreneurship in the society and identifying factors other than financing that prevent entrepreneurship.

\section{References}

Alada, A.D. (2001). Notes on Entrepreneurship in the History of Economic Thought. Istanbul University Faculty of Political Science Magazine, (23-24), 47-52.

Akat, I., Budak, G., and Budak, G. (1997). Business Administration, Izmir: Barış Publications

Arıkan, S. (2004). Entrepreneurship, Some Basic Concepts and Current Issues, Expanded 2nd Edition, Siyasal Publishing House, Ankara, 251-253.

Balaban, Ö., \& Özdemir, Y. (2008). The effect of entrepreneurship training on the tendency of entrepreneurship: Sakarya University, Faculty of Economics and Administrative Sciences example.

Bilge, H., \& Bal, V. (2012). Entrepreneurship Tendency: A Research on Celal Bayar University Students. Journal of Suleyman Demirel University's Institute of Social Sciences, 2 (16).

Bozkurt, Ö. (2006). Importance of personality characteristics in entrepreneurship tendencies.

Cansiz, E. (2007). Determination of the entrepreneurship characteristics of university students: a study on Süleyman Demirel University students (Doctoral dissertation, Social Sciences). 
Deveci, I., \& Çepni, S. (2014). Entrepreneurship in science education teacher education. Journal of Turkish Science Education, 11 (2), 161-188.

Duygulu, E. (2008). Perceived organizational outlook, proactive personality characteristics and business start-up (entrepreneurship) attitude: A review on the students of Dokuz Eylül University Social Sciences Institute. Dokuz Eylül University Institute of Editorial Board of Social Sciences, 10 (2), 95-120.

Döm, S. (2008). Entrepreneurship and Small Business Management, Detay Publishing, $2^{\text {nd }}$ Edition, Ankara.

Fis, A.M., \& Wasti, S.A. (2009). Relationship between organizational culture and entrepreneurship tendency. 1.METU Studies in Development, 35, 127.

Galloway, L., \& Brown, W. (2002). Entrepreneurship education at university: a driver in the creation of high growth firms? Education + Training, 44 (8/9), 398-405.

Gürer, A., Sezen, S. and Solmaztürk, A.B. (2014). A Field Research on Measuring the Entrepreneur Personality Characteristics of University Students, Third Sector Social Economics, 49 (2), (1-19).

Gürdoğan, N. (2008). Girişimcilik ve girişim kültürü. İGİAD yayınları.

Gürol, M.A. (2000). Women entrepreneurs and their small businesses in Turkey: opportunities, problems, expectations, and suggestions (Vol. 2). Atılım University.

Hébert, RF, \& Link, A.N. (1988). The entrepreneur: mainstream views \& radical critiques. Praeger Publishers.

Iscan, Ö. F., \& Kaygin, E. (2011). A survey to determine the tendencies of entrepreneurship among university students as potential entrepreneurs. Organization and management sciences magazine, 3 (2).

Kantur, D. (2007). Corporate Entrepreneurship Theme and Its Measurement. In Corporate Entrepreneurship Construct and its Measurement), Proceedings of the 15th National Management and Organization Congress (pp. 133-142).

Keleş, H.N., Özkan, T.K., Doğaner, M., \& Altunoğlu, A.E. (2012). A Research for Determining Levels of Entrepreneurship of Associate Students. International Journal of Economics and Administrative Studies, (9).

Kılıç, S., \& Aydın, D.G. (2015). Economic And Social Transformation and Innovative Entrepreneur. Journal of Faculty of Economics and Administrative Sciences , 16 (3), 143-158.

Kırılmaz, S.K. (2013). A study for the determination, entrepreneurship and transformational leadership perceptions of social entrepreneurs. Entrepreneurship and Development Journal , 8 (1).

Kizılkaya, E. (2005). A Note on the Joseph A. Schumpeter's Idea of Entrepreneurship. Mediterranean Journal of Economics and Administrative Sciences Faculty, 10 , 26-45.

Klofsten, M. (2000). Training entrepreneurship at universities: a Swedish case. Journal of European Industrial Training, 24(6), 337-344. 
Köksal, Y., \& Penez, A.G.S. (2015). A survey of demographics and sector preferences of college students that are highly prone to entrepreneurship. Süleyman Demirel University Faculty of Economics and Administrative Sciences Journal , 20 (1).

Kuyan, H. (2007). Life and Working Values of the Turkish Entrepreneurs: A Research on Entrepreneurs in Malatya, Unpublished PhD Thesis.

Müftüoğlu, T., \& Durukan, T. (2004). Entrepreneurship and SMEs. Gazi Publications, Ankara .

Rasmussen, E.A., \& Sorheim, R. (2006). Action-based entrepreneurship education. Technovation , 26 (2), 185-194.

Ripsas, S. (1998). Towards an interdisciplinary theory of entrepreneurship. Small Business Economics , 10 (2), 103-115.

Tekin, M. (2004). Entrepreneurship and Small Business Management , $4^{\text {th }}$ Edition, Ankara.

Titiz, T. (1999). Recommendations for Young Entrepreneurs, İnkılap Bookstore.

Top, S. (2006). Entrepreneurship: discovery process . Beta.

Turan, Z., Nakiboğlu, A., \& Cetinkaya, N. (2015). Teachings on Economy And Marshall. Electronic Turkish Studies .

Van Praag, CM (1999). Some classic views on entrepreneurship. De Economist , 147 (3), 311-335.

Yılmaz, E., \& Sünbül, A. M. (2009). Üniversite öğrencilerine yönelik girişimcilik ölçeğinin geliştirilmesi. Selçuk Üniversitesi Sosyal Bilimler Enstitüsü Dergisi, (21), 195-203.

Yurtseven, H.R. (2007). Entrepreneurship: to establish and to manage a small business . Detay Publishing.

Yüzüak, E. (2010). Factors affecting entrepreneurship tendencies of female students studying at universities: 18 ${ }^{\text {th }}$ March University of Çanakkale Biga: Faculty of Economics and Administrative Sciences example (Master's thesis, Çanakkale $18^{\text {th }}$ March University Institute of Social Sciences).

Weber, M. (2009) The Protestant Ethic and the Spirit of Capitalism, trans. Zeynep Gürata, Ayraç Publications, Ankara.

Wennekers, S., \& Thurik, R. (1999). Linking entrepreneurship and economic growth. Small business economics, 13(1), 27-56. 